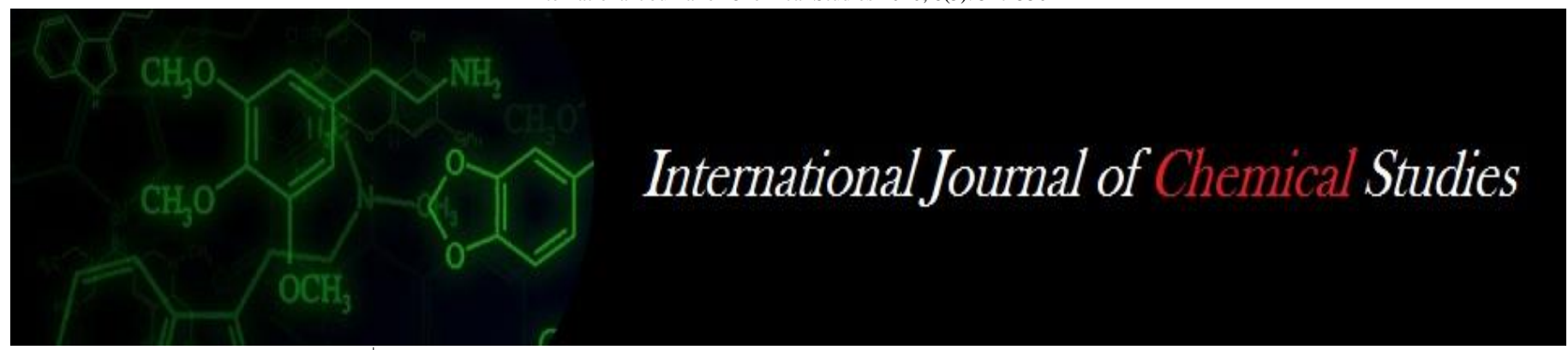

P-ISSN: 2349-8528

E-ISSN: 2321-4902

www.chemijournal.com

IJCS 2020; 8(5): 547-550

(C) 2020 IJCS

Received: 10-06-2020

Accepted: 08-08-2020

Ashoka P

Senior Scientist and Head,

ICAR-Krishi Vigyan Kendra,

Ranebennur Taluk, Haveri

District, Karnataka, India

Priya $\mathbf{P}$

Assistant Professor, Department of Agronomy, College of

Agriculture, Hanumanamatti,

Ranebennur Taluk, Haveri

District, Karnataka, India

Sarojani J Karakkannavar Professor and Head, Department of Food Science and Nutrition, College of Community Sciences, Dharwad, Karnataka, India
Corresponding Author: Ashoka P

Senior Scientist and Head, ICAR-Krishi Vigyan Kendra, Ranebennur Taluk, Haveri District, Karnataka, India

\section{Productivity and profitability analysis of sunflower (Helianthus annuus L.) through front line demonstrations in Northern transitional Zone on Karnataka}

\author{
Ashoka P, Priya P and Sarojani J Karakkannavar
}

DOI: https://doi.org/10.22271/chemi.2020.v8.i5h.10352

\begin{abstract}
Front line demonstration (FLD) is an appropriate means for demonstration as well as transfer of improved agricultural innovations to the farming community. Under centrally sponsored scheme on oilseed production technology under NMOOP scheme. The constraints in the production of sunflower crop were identified with a major emphasizes against the pest and diseases in the sunflower. The critical inputs required were identified from the recommended package of practices of Karnataka and their usages were discussed in practicing farmer's trainings at the farmer's field. The average two years data revealed that an average yield of demonstrated plot was obtained 15.81/ha over local check $10.75 \mathrm{q} / \mathrm{ha}$ and the average percentage increase in yield over local check was 52.87 per cent. The average extension gap was found to be 6.68. The hybrid DSFH-3 and KBSH-53 performed better at front line demonstrated plot as compared to local check. Further, benefit: cost ratio was recorded to be higher under demonstrated plot against local check during the study. Further, average higher benefit- cost ratio (2.45) was recorded under demonstrated plot against check (1.96). The yield levels were considerably low under local practices because of considerable variations in the extent of adoption of recommended package of practices depending upon the amount of risk involved in terms of cost, convenience, skill and knowledge about the concerned practice. The productivity was better over local practice under demonstrations. Hence, sunflower production technology have a broad scope for increasing the area and production at each and every level i.e., Farmers, State and National level.
\end{abstract}

Keywords: Extension gap, frontline demonstrations, yield, performance, sunflower

\section{Introduction}

Sunflower (Helianthus annuus L.) known as "Golden Girl of American Agriculture". The name has its origin in Greek "Helios" means "Sun" and "Anthois" means flower. It is native to southern parts of USA and Mexico. In the Asian continent, after China, India is the second largest sunflower growing country. In India, edible oilseeds are cultivated over an area of 19 million hectares with 17 million tonnes production. Peanut, rapeseed mustard, sunflower, sesame and safflower are the major edible oilseed crops. However, about 75 per cent of the total oilseed production is contributed by peanut and rapeseed mustard. The Oilseeds are the second largest agricultural commodities in India after cereals accounting for about 14 per cent of the cropped area, contributing 5 per cent to the gross national product and 10 per cent of the value to all agricultural products. At present, the oilseeds production in India is not meeting the domestic demands and now dependent on imports. The continuous increase in import of oilseed is a matter of great concern today (Katare et al., 2011) ${ }^{[1]}$. A wide gap exists in sunflower production with the use of available techniques and its actual application by the farmers and the higher incidence of pest attack leads to further reduction in yield, reflected through poor yield of sunflower crop on farmer's field. There is a tremendous opportunity for increasing the productivity of sunflower crop by adopting the improved technologies. To demonstrate the scientific cultivation of sunflower front line demonstrations should be laid out at farmer's field. The basic objective of FLDs is to demonstrate the proven technology at farmer's field through KVKs (Verma et al., 2014) ${ }^{[2]}$. In recent years sunflower has emerged as a potential oilseed crop in both rainfed and irrigated farming. 
It is a major source of vegetable oil in the world. In India it has gained popularity due to the national priority of vegetable oil production. India is one of the largest producers of oilseed crop in the world. Oilseeds occupy an important position in the Indian agricultural economy. Sunflower oil is considered as premium when compared to other vegetable oils. Sunflower oil has a high nutritional value and good taste. It is composed mainly of unsaturated fatty acids like linoleic (50$65 \%)$ and oleic $(25-40 \%)$.

In India, sunflower is being grown over an area of 2.13 million hectares with a production of 1.12 million tones and contributing considerably for edible oil sector of the nation. Karnataka is one of the major sunflower growing state and leading in the country by contributing 53 and 35 per cent of total area and production, respectively. It is the second important oilseed crop after groundnut in the state having an area of 1.43 million hectares with production of 0.42 million tones. However, productivity (372 kg ha-1) is lesser than the national average of $566 \mathrm{~kg}$ ha-1 (Anon., 2007) ${ }^{[3]}$. Thus, there is a thrust for improving the productivity of oilseeds through exploitation of commercial untapped yield reservoir through effective hybridization programmes by identifying superior and better lines and further their purity maintenance (Math et al., 2017) ${ }^{[4]}$. Front line demonstration is one of the most powerful tools of extension because farmers in general, are driven by the perception that "seeing is believing". Keeping in view the importance of FLDs, the ICAR-Krishi Vigyan Kendra, Hanumanamatti, Haveri district of North Karnataka conducted demonstrations on sunflower at farmers' field under rainfed and irrigated situations from 2016-18. With this objectives of the study was formulated, to know the impact of sunflower Frontline Demonstrations (FLDs) on farmers field, to study the cost of cultivation and yield level of sunflower Dayanand, Verma, R.K. and Mahta, S.M. (2012) ${ }^{[5]}$. Finally compared the yield of local check (farmers' field) and FLD fields. The area of high yielding hybrid of sunflower has increased which will spread in the taluk including the adjoining area. The selection of critical input and participatory approach in planning and conducting the demonstration definitely help in the transfer of technology to the farmers.

\section{Materials and method}

The experimental study area, comes under Zone -3, Northern Dry Zone which lies between $14^{\circ} .28^{\prime}$ and 14.39' North latitude and $75^{\circ} .40^{\prime}$ and $77^{\circ} .11^{\prime}$ 'East longitude. The AEEC has varied climatic, topographic, soil and water resources and cropping systems. The present study was conducted for five years (2016-17 to 2018-19). In total 115 demonstrations were conducted in different villages of Haveri district of Karnataka. The villages were selected based on the participatory Rural Appraisal method and cultivation practices of the Haveri District. The blocks are namely ICAR-Krishi Vigyan Kendra, Hanumanamatti, Haveri district, in an area of 46 ha at 115 beneficiary fields. Field days and group meetings were also organized at the demonstration sites to provide opportunities for other farmers to observe and witness the benefits of demonstrated technologies. The critical inputs were duly supplied to the farmers by the ICAR-Krishi Vigyan Kendra, Hanumanamatti. Data were collected from the FLDs farmers and analysed with the suitable statistical tools to compare the yield of farmers' fields and FLD fields. The data output were collected from both FLD plot as well as check plots and finally the extension gap (Katare et al., 2011) ${ }^{[1]}$ along with the benefit cost ratio were worked out (Samui et al., 2000) ${ }^{[61]}$.
The sunflower seed was treated with Imidachloprid $6 \mathrm{ml} / \mathrm{kg}$ of seed to avoid pest and disease. The critical inputs viz., sunflower seed were distributed to the beneficiaries. Farmers were trained to follow the package of practices as per University of Agricultural Sciences, Dharwad for sunflower cultivation. The farmers followed the full package of practices like seed treatment, biofertilizer \& fertilizer application, irrigation and weed management, insect-pest management etc. In case of local check, the traditional practices were followed in existing varieties by the farmers. In general the soils under study was sandy loam in texture with a $\mathrm{pH}$ ranging between 7.1 -7.5. The sowing of the sunflower seeds should be done by August to October in Rabi season and in summer sowing done during December to January. The $5 \mathrm{~kg}$ seed were sown per hectare. Ridge sowing were done and the seeds were placed about $6-8 \mathrm{~cm}$ below the ridge top. Irrigated to ridge sown crop at 2-3 days after sowing and care was taken that, water level in the ridges well below the seed placement line. The yield parameters were recorded for both check and demonstrated variety of sunflower.

The demonstration of improved technology was taken in area of 0.05 ha of each farmer. These varieties were compared with farmers practice i.e. treated as a control. The result was compared with the full package of practice. The primary data on output of millets yield were collected from the selected farmers in FLD plots, besides the data on local practices commonly adopted by the farmers of this region were also collected with the help of interview schedule and presented in term of percentage and qualitative data was converted in to quantitative form and expressed in term of percent increased yield was calculated by the using formula. The average yield of each FLD and farmers practice, cost of cultivation, gross return, net return and benefit cost ratio (B: $\mathrm{C}$ ratio) was taken for interpretation of the results. The extension gap, technology gap and technology index were calculated using the following formula as suggested by Samui et al. (2000).

Extension gap $=$ Demonstration yield - Local check yield Technology gap $=$ potential yield - Demonstration yield Technology index $=$ Potential yield - Demonstration yield $\mathrm{x}$ 100/Potential Yield

$\%$ Increase over farmers practice $=\stackrel{\text { Improved practice }- \text { Framers practice }}{\mathrm{X} 100}$

Framers practice

The yield data were collected for with the two recommended and one control plots (farmer practice). Their feasibility and economics variability were accessed the trial was also envisaged with four fundamental assumption

a. When the technology is not acceptable for the farmer in it recommended form and needs minor modification, refinement or change.

b. It needs the integration of related indigenous knowledge of the farmers with the scientific recommendation in the process of refinement or modification, moreover the refinement or modification is a continuous process in the lake of available technological option specific to each microenvironments.

c. The collaboration of farmers who has been experimenting on their own to evolve solutions to the constraints, in their farm and of the extension system which is vital in the process of technology development.

d. The technology or practices generation through Front Line Demonstrations become farmer's recommendation 
comprising a basket of after natures and as the most appropriate to solve problem. Keeping above in view the Front Line Demonstrations were executed. There were performance indicator and economic indicates considered to execute the trial.

\section{Results and Discussions}

The difference between the demonstration package and existing farmers practices are given in Table 1 . The data on average cost of cultivation, average gross return, average net return and benefit: cost ratio were collected from frontline demonstrations plots for working out the economic feasibility of sunflower hybrids. The recommended packages of practices were followed at the farmer's field. The difference between the demonstration package and existing farmers practices are given in Table 2.

The average yield of two years in demonstrated plot was $15.81 \mathrm{q}$ ha against local check (10.75 q/ha). The per cent increase in yield was 52.87 per cent over local check (Table 1). The sunflower yield is increased from 1.5-2.0 t/ha due to adopting improved production technology. Thus, there is a gap of 2.97 to $5.61 \mathrm{t} / \mathrm{ha}$ on yield has recorded in between improved agronomic practices and farmers field. Among the varieties DSFH-3 and KBSH-53, was found superior and yield increase was by 69.49 and 19.62 respectively.

Further, average higher benefit- cost ratio (2.45) was recorded under demonstrated plot against check (1.96). The results clearly indicated the positive effects of FLDs over the existing practices towards enhancing the yield of the sunflower hybrids (Anuj Kumar Singh et al., 2017) ${ }^{[7]}$. The reason for the higher yield in FLDs is due to application of recommended dosages of fertilizers and proper pest management practices against the pest and diseases. However, yield of the different hybrids were varied in different years which might be due to the variation in climatic conditions and incidence of disease/ pest attack. The technological gap i.e. the difference between potential yield and yield of demonstration plot were varied between $6.11 \& 2.97$ during the year 2017-18 and 2.18-19 respectively. The average technology gap in all the years was 5.06. Technology gap imply researchable issues for realization of potential yield, while the extension gap imply what can be achieved by the transfer of existing technologies. The technological index revealed the feasibility of the demonstration technology. As such variation in technology index varied between 36.66 to 19.55 during the study period in certain area may be attributed to dissimilarity in the soil fertility condition, pest-diseases attack, non availability and poor quality of irrigation water and weather condition. Similar results were also recorded by Vikram et al., (2018) ${ }^{[8]}$ and Rupesh (2015) [9] in sunflower, Anuja et al. 2014) ${ }^{\text {[7] in }}$ different oilseeds crops, Balai et al., (2012) ${ }^{[10]}$ in rapeseed mustard and Berjesha et al., (2013) ${ }^{[11]}{ }^{[3]}$ in Brassica.

The extension gap showed the trend ranged from 8.25 to $4.41 \mathrm{q} /$ ha during the period of study (Table 2 ). The percentage increases in yield over local check were recorded constantly year wise during the period of study.

Table 1: Details of sunflower hybrids growing under existing farmer's practices and improved practices adopted in frontline demonstrations at farmer's field

\begin{tabular}{|c|c|c|c|}
\hline $\begin{array}{l}\text { Sl. } \\
\text { No. }\end{array}$ & Operations & Existing farmers practice & $\begin{array}{c}\text { Improved/ Recommended practices adopted in } \\
\text { demonstration plot (FLDs) }\end{array}$ \\
\hline 1 & Farming situation & Rainfed & Rainfed \\
\hline 2 & Time of sowing & Second Fortnight Of July & Second fortnight of August \\
\hline 3 & Seed treatment & Not done & Treatment with imidachloprid $6 \mathrm{ml} / \mathrm{kg}$ of seed \\
\hline 4 & Method of sowing & Sowing & Ridge sowing/ Dibbling \\
\hline 5 & Fertilizers dosage & $\begin{array}{l}\text { Non-adoption of recommended package of practices. } \\
\text { Usually more emphasizes were done on the higher } \\
\text { dosages of urea and application of Muriate of potash } \\
\text { (MOP) is omitted due to higher cost. }\end{array}$ & $\begin{array}{c}\text { Urea- } 50 \mathrm{~kg} / \mathrm{acre} \\
\text { Single Superphosphate- } 75 \mathrm{~kg} / \mathrm{acre} \\
\text { Muriate of Potash- } 20 \mathrm{~kg} / \mathrm{acre}\end{array}$ \\
\hline 6 & Weed control & hoeing and hand weeding & $\begin{array}{c}\text { First hoeing was done 2-3 weeks after the emergence } \\
\text { followed by second hoeing three weeks thereafter and } \\
\text { application of Stomp } 30 \text { EC (Pendimethalin) @ 1litre/acre as } \\
\text { pre-emergence within 2-3 days after sowing }\end{array}$ \\
\hline 7 & $\begin{array}{l}\text { Plant protection } \\
\text { Measures (Pest } \\
\text { Incidences) }\end{array}$ & $\begin{array}{l}\text { No adoption of recommended package practices and } \\
\text { injudicious use of pesticides and spray. }\end{array}$ & $\begin{array}{c}\text { Imidachloprid 17.8 EC @ 0.25ml/lit } \\
\text { Dusting melathion @ } 20 \mathrm{~kg} / \mathrm{ha} \text { or Quinolphos 25 EC @ } 2 \\
\text { ml/lit for insect pest management. Mancozeb 75 WP @ } 2 \mathrm{gm} \\
\text { or Hexaconazole 5 EC @ } 1 \mathrm{ml} / \text { lit or Difenconazole 25 EC @ } \\
1 \mathrm{ml} / \mathrm{lit} .\end{array}$ \\
\hline
\end{tabular}

Table 2: Performance of frontline demonstrations on sunflower (Helianthus annus L.) hybrids

\begin{tabular}{|c|c|c|c|c|c|c|c|c|c|c|c|}
\hline \multirow{2}{*}{ Year } & \multirow{2}{*}{ Variety } & \multirow{2}{*}{ Area } & \multirow{2}{*}{$\begin{array}{l}\text { No of } \\
\text { demos }\end{array}$} & \multicolumn{2}{|c|}{ Yield (Q/acre) } & \multirow{2}{*}{$\begin{array}{l}\text { \% increase in yield } \\
\text { over local check }\end{array}$} & \multirow{2}{*}{ TG } & \multirow{2}{*}{ EG } & \multirow{2}{*}{ TI } & \multicolumn{2}{|c|}{ B:C ratio } \\
\hline & & & & Demo & Check & & & & & Demo & Local check \\
\hline \multirow{2}{*}{ 2016-17 } & DSFH-3 & 17.2 & 43 & 14.25 & 8.64 & 64.93 & 5.61 & 8.25 & 36.66 & 2.01 & 1.53 \\
\hline & KBSH-53 & 8.8 & 22 & 15.10 & 8.48 & 74.06 & 6.62 & 7.40 & 32.88 & 2.33 & 1.77 \\
\hline $2017-18$ & KBSH-53 & 20 & 50 & 18.10 & 15.13 & 19.62 & 2.97 & 4.41 & 19.55 & 3.02 & 2.59 \\
\hline \multicolumn{4}{|c|}{ Average } & 15.81 & 10.75 & 52.87 & 5.06 & 6.68 & 29.69 & 2.45 & 1.96 \\
\hline
\end{tabular}

Extension Gap= Demonstration - Farmers yield

TG=Technology gap

EG=Extension Gap

$\mathrm{TI}=$ Technology Index

\section{Conclusion}

The study has shown that the FLD programme was found useful in enhancing the knowledge and adoption level of farmers in various adoption levels of farmers in various aspects of sunflower production technologies. The findings of the demonstration revealed that, the percent increment in yield of sunflower to the extent of $52.87 \%$ in frontline demonstrations over the farmers practice. This has created the 
greater awareness and motivated the other farmers to adopt the improved package of practices of sunflower. These demonstration trails also enhance the relationship between farmers and scientists and reduce the technological gap and to reverse the trend of extension gap, emphasizes is required to conduct more number of practising farmer's training at farmer's field and KVK campus regarding recommended package of practices.s

\section{References}

1. Katare S, Pandey SK, Mustafa M. Yield gap analysis of rapeseed-mustard through front line demonstrations. Agricultural Update. 2011; 6(2):5-7.

2. Verma RK, Dayanand Rathore RS, Mehta SM, Singh M. Yield and gap analysis of wheat Productivity through frontline demonstrations in Jhunjhunu district of Rajasthan. Ann. Agric. Res. New Series. 2014; 35(1):7982.

3. Anonymous, Karnataka at a Glance, 2007, 2016-17.

4. Math G, Vijayakumar AG, Hegde Y, Basamma K. Impact of improved technologies on productivity enhancement of sesame (Sesamum indicum L.). Indian Journal of Dryland Agricultural Research and Development. 2017; 29(2):41-44.

5. Dayanand, Verma RK, Mahta SM. Boosting the mustard production through front line demonstrations. Indian Research Journal of Extension Education. 2012; 12(3):121-123.

6. Samui SK, Maitra S, Roy DK, Mandal AK, Saha D. Evaluation of Front Line demonstration on groundnut. Journal of Indian Society for Coastal Agricultural Research. 2000; 18(2):180-18.

7. Anuj Kumar Singh, Kinjulck Singh C, Singh YP, Singh DK. Impact of frontline demonstration on Adoption of improved practices of Oilseed Crops. Indian Res. J Ext. Edu. 2014; 14(3):75-77.

8. Vikram Bharati. Performance of FLD Intervention on yield of sunflower (Helianthus annus L.) in Bihar, India, International Journal of current microbiology and applied sciences. 2018; 7(3):2878-2881.

9. Rupesh Kumar Arora. Performance of Front Line Demonstartions on Sunflower (Helianthus annuus L.) in Ambala District, Haryana, India. American International Journal of Research in Formal, Applied \& Natural Sciences. 2015; 9(1):33-35.

10. Balai CM, Meena RPBL, Bairwa RK. Impact of Front Line Demonstartion on Rapeseed-Mustard Yield Improvement. Indian Res. J Ext. Edu. 2012; 12(2):115.

11. Berjesh Ajrawat, Manu Parmar A, Mahital Jamwal. Impact of front line demonstration of oilseed crops in improved technology transfer. Journal of Oilseed Brassica. 2013; 4(2):96-97. 